\title{
Modeling the Impact of Urban Three-Dimensional Expansion on Atmospheric Environmental Conditions in an Old Industrial District: A Case Study in Shenyang, China
}

\author{
Chunlin $\mathrm{Li}^{1}$, Yanyan Xu${ }^{2}$, Miao Liu' ${ }^{1 *}$, Yuanman $\mathrm{Hu}^{1}$, Na Huang ${ }^{3}$, Wen $\mathrm{Wu}^{4}$ \\ ${ }^{1}$ CAS Key Laboratory of Forest Ecology and Management, Institute of Applied Ecology, \\ Chinese Academy of Sciences, Shenyang, China \\ ${ }^{2}$ School of Architecture, Tianjin Chengjian University, Tianjin, China \\ ${ }^{3}$ School of Architecture and Urban Planning, Shenyang Jianzhu University, Shenyang, China \\ ${ }^{4}$ Jangho Architecture College, Northeastern University, Shenyang, China
}

Received: 5 August 2019

Accepted: 15 October 2019

\begin{abstract}
The rapid expansion of cities has caused enormous changes in the underlying surface, and coupled with the intensification of human activities, it has resulted in a series of ecological and environmental problems, such as urban heat island, air pollution, and so on. Through combining building height and air pollution source information, and using the computational fluid dynamics (CFD) model, this study simulated the distribution characteristics of wind speed, temperature and $\mathrm{SO}_{2}$ concentration under the condition of urban three-dimensional expansion, and then the analysis was performed on the influence of three-dimensional expansion on air environment diffusion during winter and spring in the Shenyang Tiexi District under the urban landscape pattern of 2005 and 2011. Monitoring data from 10 sampling sites were used to validate the model. The results showed that the $\mathrm{R}^{2}$ values for wind speed, temperature and $\mathrm{SO}_{2}$ were $0.76,0.79$ and 0.64 , respectively. The wind speed, temperature and $\mathrm{SO}_{2}$ concentration distribution pattern at the same height of the study area is obviously different because of the differences in urban building height, density and layout between 2005 and 2011. From 2005 to 2011, with the change in the urban architecture landscape pattern, the city corridor significantly changed.
\end{abstract}

Keywords: computational fluid dynamics, pollutant diffusion, atmospheric environment, simulation, urban three-dimensional expansion

*e-mail: lium@iae.ac.cn 


\section{Introduction}

The world is currently undergoing an unprecedented process of urbanization that has resulted in numerous adverse effects on the environment, economy and society. Urbanization-driven land use changes the urban microclimate [1]. An important environmental impact is increasing air pollution [2]. The increase in impervious surfaces following urbanization without reasonable urban planning, and increased energy consumption in response to the growth of the urban population in metropolitan regions, exacerbate air pollution [3]. Air pollution can seriously endanger human health, particularly leading to respiratory problems, which has caused increasing concern regarding air quality [4-7].

Urbanization has a greater impact on the pollutant concentrations in some areas of a city. The study of the impact of urban expansion on the atmospheric environment is mainly concentrated on the effect of urban horizontal expansion on urban air temperature and the urban heat island (UHI) effect. Researchers have shown that rapid urban expansion leads to an expansion of the UHI because the urban expansion increases surface radiant temperature in urbanized area [8-10] and the UHI effect is greater during the night than during the day [11]. Expansion of a non-vegetated area even without population growth is a significant factor related to temperature increase [12].

The urban structure has significant effects on pollution. Highly constructed cities are subject to higher $\mathrm{NO}_{2}$ and $\mathrm{PM}_{10}$ concentrations, and densely populated cities have higher $\mathrm{SO}_{2}$ concentrations [13]. Large metropolitan regions ranking highly on a quantitative sprawl index experience a greater number of ozone exceedances than more spatially compact metropolitan regions [14]. There is an increasing amount of impervious urban surface area that contributes to more severe air pollution during the urban expansion process $[15,16]$. Some studies have suggested that population, urbanization, and industrial structure all have a negative influence on the atmospheric environment [17]. Urban form may play an important role in improving air quality [18, 19]. It is hoped that during the rapid urbanization process, it is possible to put forward the best urban design scheme that is beneficial to atmospheric diffusion in terms of the climatic characteristics of the study area and is of great theoretical significance to the development of healthy urban environmental quality. Despite the potentially important effects of urban form on air quality, relatively few studies in this domain exist [20]. There are few reports regarding the impact of urban three-dimensional changes on the urban environment [21-23].

It is difficult and expensive to dynamically and accurately monitor air pollutant concentrations; thus, an atmospheric pollution diffusion model is used to simulate and predict atmospheric pollutant diffusion.
The main advantage of numerical simulation model data compared to observational data is that the model can simulate multiple scenarios and analyze the impact of different scenarios on air pollutant distribution and transport [24-26]. In addition, monitoring can only be conducted at several points and individual areas, while model simulation can obtain results for the entire region [27, 28]. Recent advancements in numerical models, such as the Reynolds average Navier stocks (RANS) equation, large eddy simulation (LES), and direct numerical simulation (DNS), etc., accurately simulate the flow field in an urban area; these models are a significant step toward plume dispersion accuracy. With advancements in computational resources and grid generation techniques, the computational fluid dynamics (CFD) models are increasingly being used to simulate pollutant transport and dispersion in urban areas [2932]. CFD is a numerical method used to numerically analyze flow motion and can adequately address most flow fields [33]. CFD is particularly suited for highresolution modeling in space and time of wind velocity, temperature and concentration fields for statistically stationary conditions [25].

As an established industrial base in northeastern China, Shenyang is undergoing rapid urbanization. According to the annual report of the Shenyang Environmental Protection Bureau, the annual averaged $\mathrm{PM}_{2.5}$ concentration in 2016 was $\sim 54 \mu \mathrm{g} / \mathrm{m}^{3}$, which is 1.5 times higher than the national standard level of China $\left(35 \mu \mathrm{g} / \mathrm{m}^{3}\right)$ [34]. During certain wintertime haze episodes, the hourly concentration of $\mathrm{PM}_{25}$ in Shenyang could even reach $1000 \mu \mathrm{g} / \mathrm{m}^{3}$ [35]. Air pollution in Shenyang was not only related to the local emissions, but also contributed by transboundary transport from the upstream region. The aerosols emitted from the Beiijng-Tianjin-Hebei region accounted for similar to $20 \%$ of near-surface $\mathrm{PM}_{2.5}$ in Shenyang [34]. Rapid urban expansion, economic growth, social development and population growth all aggravate the atmospheric environmental pollution in Shenyang. In this study, we combined 3-dimensional building heights and a CFD model to simulate the distribution of wind speed, temperature and $\mathrm{SO}_{2}$ at different heights. There were two major goals for this study: (1) develop an effective and efficient method to simulate the atmospheric environment in the Shenyang urban area and (2) simulate and analyze the distribution of wind speed, temperature and $\mathrm{SO}_{2}$ at different heights and during different years.

\section{Materials and Methods}

\section{Study Area}

Tiexi District $\left(41^{\circ} 45^{\prime} \mathrm{N}-41^{\circ} 50^{\prime} \mathrm{N}, 123^{\circ} 18^{\prime} \mathrm{E}-123^{\circ} 23^{\prime} \mathrm{E}\right)$ is part of the core urban area of Shenyang in northeastern China and has an area of $39.48 \mathrm{~km}^{2}$. Beginning in 1913, Tiexi District began to take heavy 
industry as a starting point for urban development. During the early and middle $19^{\text {th }}$ century, the Tiexi District became an important industrial base of China and was praised as the "Eastern Ruhr" as it made great contributions to the development of China. Since 1978, China has put forward a reform and opening-up policy, and the focus of economic development has shifted to the eastern coastal areas. Thus, since the 1980s, many state-owned enterprises have been in a dilemma. Many enterprises have closed, workers have been laid off and the economy has weakened. The Tiexi District was a typical representative of the recession of China's old industrial base. In 1986, the State Council listed the overall renewal of Tiexi District as a pilot project for regional renovation in China. With the decline in traditional industries and the "Retreat into three" of the industrial structural adjustment, many heavily polluting, energy-intensive and inefficient industrial enterprises have been gradually relocated, transformed or shut down. After a series of urban transformations, such as the transformation of shantytowns and dilapidated buildings, the three-dimensional urban landscape significantly changed and urban vertical expansion was significant. The construction patch density increased from 243.8 to $270.69 \mathrm{unit} / \mathrm{km}^{2}$, the average building height increased from $9.74 \mathrm{~m}$ to $19.34 \mathrm{~m}$, and the urban space congestion index increased from 1.86 to 3.38 from 1997 to 2011 [36]. The Tiexi District has a temperate continental monsoonal climate with an average temperature of $8.1^{\circ} \mathrm{C}$ and distinct seasons. The air pollutant temporal-spatial distribution characteristics were obvious in Tiexi. Air pollution is the most serious problem during winter, followed by spring and autumn. According to the China International Exchange Station Ground Climate Standard Value Daily Data Set, the wind direction in the Tiexi District is south-southwest (SSW), the wind speed is $3.5 \mathrm{~m} / \mathrm{s}$, and the temperature is $9.5^{\circ} \mathrm{C}$ during spring; during the winter the wind direction is ENE, the wind speed is $2.6 \mathrm{~m} / \mathrm{s}$ and the temperature is $-8.5^{\circ} \mathrm{C}$ [37].

Three-dimensional urban expansion mainly refers to changes in building heights inside the city. The Barista software used in building three-dimensional information extraction is a photogrammetric software developed by the Institute of Geographic Information of the University of Melbourne in cooperation with the Research Center for Space Information Cooperation [38]. In the Tiexi District, 3D information on buildings and chimneys was extracted using QuickBird images in 2005 and 2011 and the Barista software version 3.2. The urban underlying surface is very complex and it is impossible to simulate all elements in a computer model. Taking the main urban roads, green spaces and water as boundaries, the buildings within a close distance were generalized into a single building block. The height was the average height of the buildings in a block.

\section{Air Pollution Sources}

Sulfur dioxide $\left(\mathrm{SO}_{2}\right)$ was the main air pollutant considered in this atmospheric pollutant diffusion simulation of Tiexi. Polluting $\mathrm{SO}_{2}$ in the atmosphere mainly originates from combustion of coal, oil, natural gas and other sulfur fuels and the production process using sulfur raw materials. $\mathrm{SO}_{2}$ emissions from coal combustion in China account for more than $90 \%$ of total $\mathrm{SO}_{2}$ emissions [39]. Thus, in this study, the chimneys of industrial enterprises in Shenyang were used as the source of $\mathrm{SO}_{2}$ emissions. The pollution sources were simplified by using the Gaussian diffusion model and a continuous discharge point source diffusion model.

There are 79 industrial chimneys throughout Tiexi District (Fig. 1). These chimneys are mainly concentrated in manufacturing enterprises and heating companies. According to an investigation of the enterprises, the inner diameter of the chimney outlets is $1.5-5 \mathrm{~m}$, and the height of the chimney is $50-210 \mathrm{~m}$. The flue gas speed at the chimney outlet is $10-20 \mathrm{~m} / \mathrm{s}$ in the case of a boiler adopting a mechanical ventilation mode and full load operation, and the $\mathrm{SO}_{2}$ emission rate is $20-157 \mathrm{~g} / \mathrm{s}$. The flue gas temperature at the exit of the chimney is $120-180^{\circ} \mathrm{C}$ after flue gas desulfurization. The flue gas temperature at the exit of the chimney in this study was set to $120^{\circ} \mathrm{C}$, i.e., $\mathrm{T}=393.15 \mathrm{~K}$. We assumed that the chimney discharge was continuous during the simulation. The parameters of industrial chimneys were used in the CFD modeling.

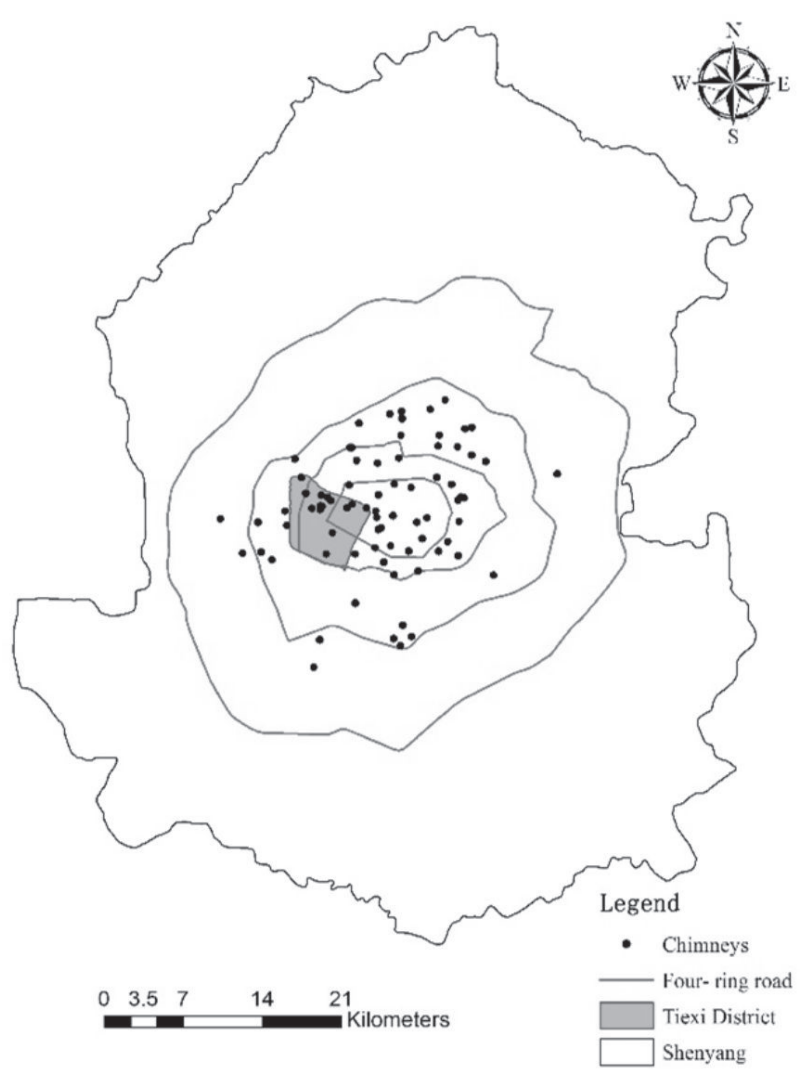

Fig. 1. Study area and chimney distribution. 


\section{CFD Simulation}

The simulation and computation of air pollution diffusion in the Tiexi District was performed using CFD simulation (ANSYS-FLUENT software). The air within the simulation domain can be considered as an incompressible turbulent flow and the air and pollutant densities are assumed to be constant. Pollutant diffusion is regarded as a purely physical diffusion process without considering the chemical changes of pollutants during the process of pollutant emissions from chimneys. The governing equations for airflow are the continuity equation and the steady Reynolds-averaged Navier-Stokes equations coupled with the standard $\mathrm{k}-\varepsilon$ turbulence model [40]. The employed turbulent model used in the CFD was the $\mathrm{k}-\varepsilon$ model, which has good atmospheric boundary layer estimation accuracy [33, 41, 42].

We interpreted the three-dimensional building height information in Barista, then we imported the building information into AutoCAD to draw a threedimensional geometric model of the Tiexi District, and finally imported the model file into GAMBIT of Fluent for mesh generation. A structured grid generation method was used to mesh the regular building blocks. To achieve more accurate simulation results, this mesh generation was based on the size of the building blocks to select different grid sizes. Based on the requirements of the computer configuration and the accuracy of the calculation results, the grid size of buildings was $5,10,15,20$ and $25 \mathrm{~m}$ after many adjustments. The chimneys were divided into unstructured grids. The chimney outlets and the chimney walls were divided into 1.0-m-sized grids. The size of the CFD domain was $50,000 \times 50,000 \times 250 \mathrm{~m}$.

\section{Field Measurements for CFD Validation}

According to several CFD best practice guidelines [25, 43, 44], CFD simulations should be critically evaluated and the results should only be considered reliable after comparison to some measurement data. Validation of CFD simulations with experimental data is essential [30]. Many studies have validated the accuracy of using CFD to simulate the diffusion of urban wind and polluted gas [45, 46], which indicated that CFD can be applied to the study of urban heat islands and air pollution in complex urban terrain [24, 47]. We simulated wind flow, surface temperature and $\mathrm{SO}_{2}$ for the Tiexi District by using observed data on November 24, 2013. Ten sampling sites were selected for monitoring in the Tiexi District in industrial, commercial and residential zones. Portable air quality monitoring was used to collect data at a sampling height of $1.5 \mathrm{~m}$. The frequency of the measured data was collection once per minute. At each sampling point, we continued to monitor for 10 minutes, and then the average value of wind flow, surface temperature and $\mathrm{SO}_{2}$ concentrate was used for validation.

\section{Results and Discussion}

\section{CFD Model Validation}

Meteorological data on November 24, 2013 from a nearby meteorological station were used for input into the CFD model to simulate the air conditions. The simulated wind flow, surface temperature and $\mathrm{SO}_{2}$ concentrations using the CFD model were evaluated against the measured values of the same day.

By comparing the simulation results to the monitored data, the difference in wind speed was $0.36-1.35 \mathrm{~m} / \mathrm{s}$, the difference in temperature $0.50-1.50^{\circ} \mathrm{C}$, and the difference in $\mathrm{SO}_{2}$ concentration $0.01-0.02 \mathrm{mg} / \mathrm{m}^{3}$ (Fig. 2). Through regression analysis of the simulation results and monitoring data, we found that the correlation coefficients of wind speed, air temperature and $\mathrm{SO}_{2}$ concentration are $0.76,0.78$ and 0.64 , respectively, which indicated a good degree of fitting between the numerical simulation and the observation. The simulation results can reflect the actual situation of the city in terms of wind, temperature and $\mathrm{SO}_{2}$ concentration to a certain extent and can meet the simulation precision requirement of a regional scale. Therefore, it is feasible to use CFD to simulate the diffusion of urban air pollutants.
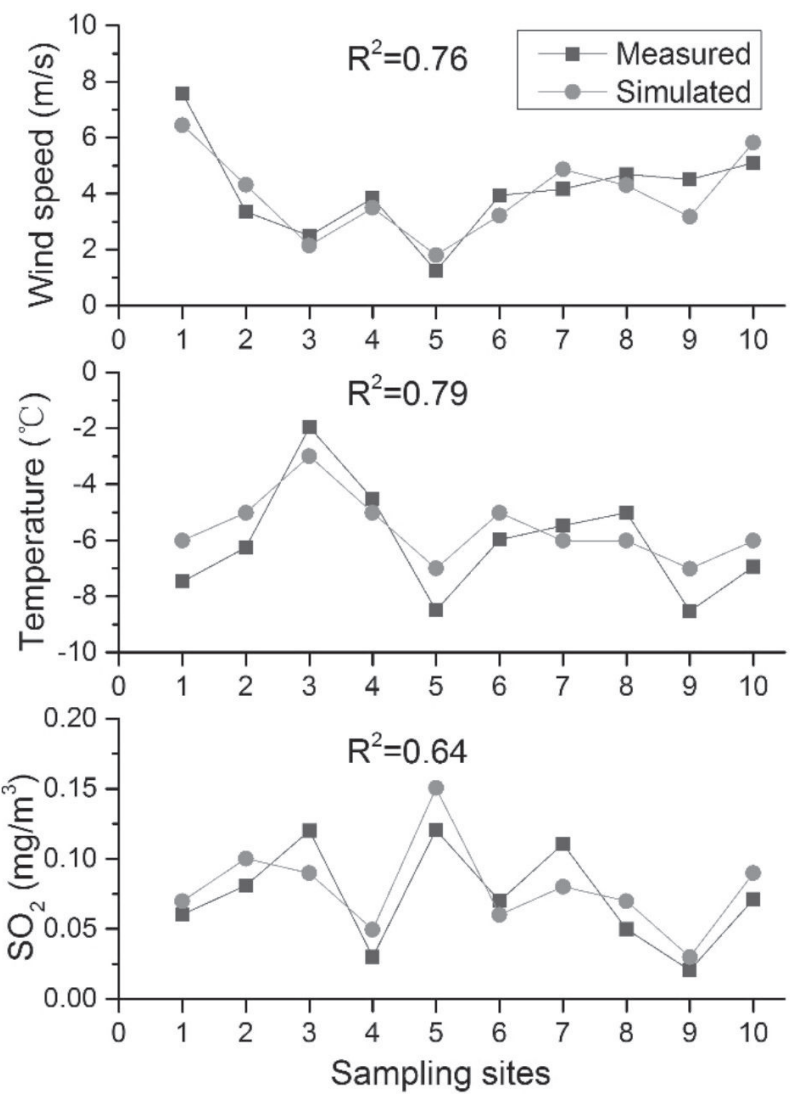

Fig. 2. Comparison of the simulated and measured values of wind flow, surface temperature and $\mathrm{SO}_{2}$. 
Wind Speed Distribution at Different Heights

The wind speed at different heights was simulated using the CFD model. Five sections with different heights $(H=1.5,10,30,50,80$, and $100 \mathrm{~m})$ were selected to analyze the wind speed, temperature and $\mathrm{SO}_{2}$ concentration characteristics. Fig. 3 shows the horizontal distribution of urban wind speed at different vertical heights during the winter and spring of 2005 and 2011. With the increase in height, the resistance of the building to the wind speed distribution gradually decreases, while the urban areas affected by a strong wind gradually increase. With the increase in height, the difference between the maximum and minimum wind speeds gradually increases. In the wind speed field of the bottom and
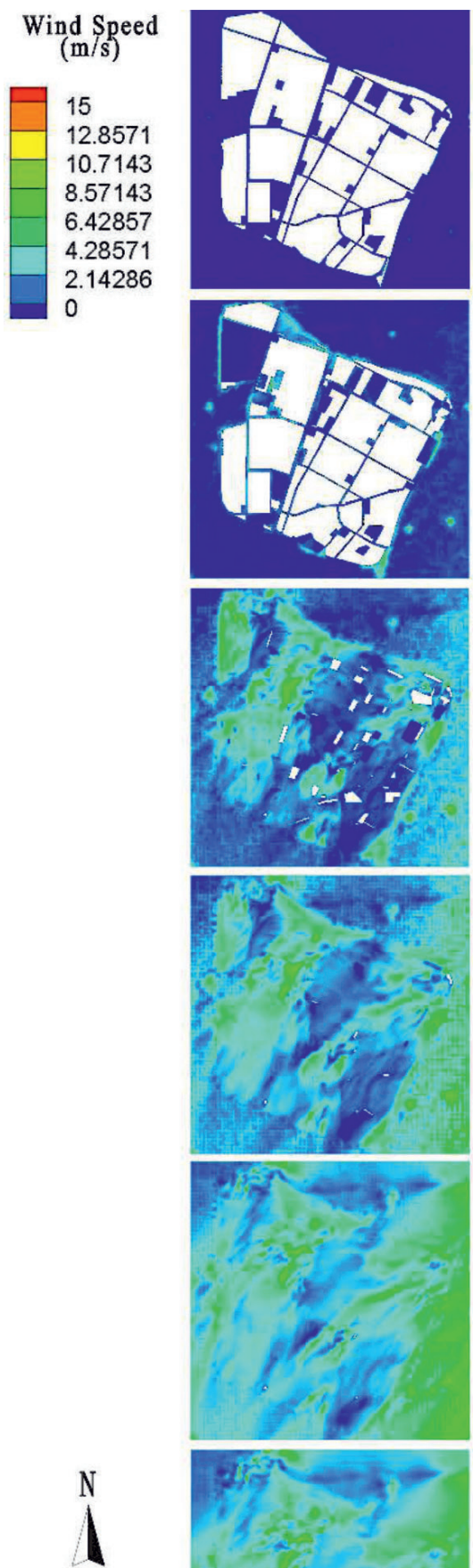

$\begin{array}{llll}0 & 1 & 2 & 4 \mathrm{~km}\end{array}$

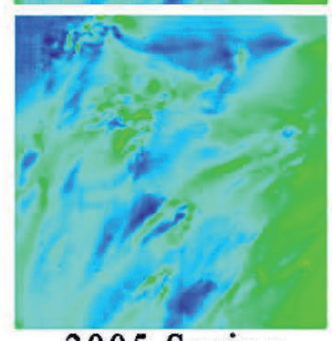

2005 Spring
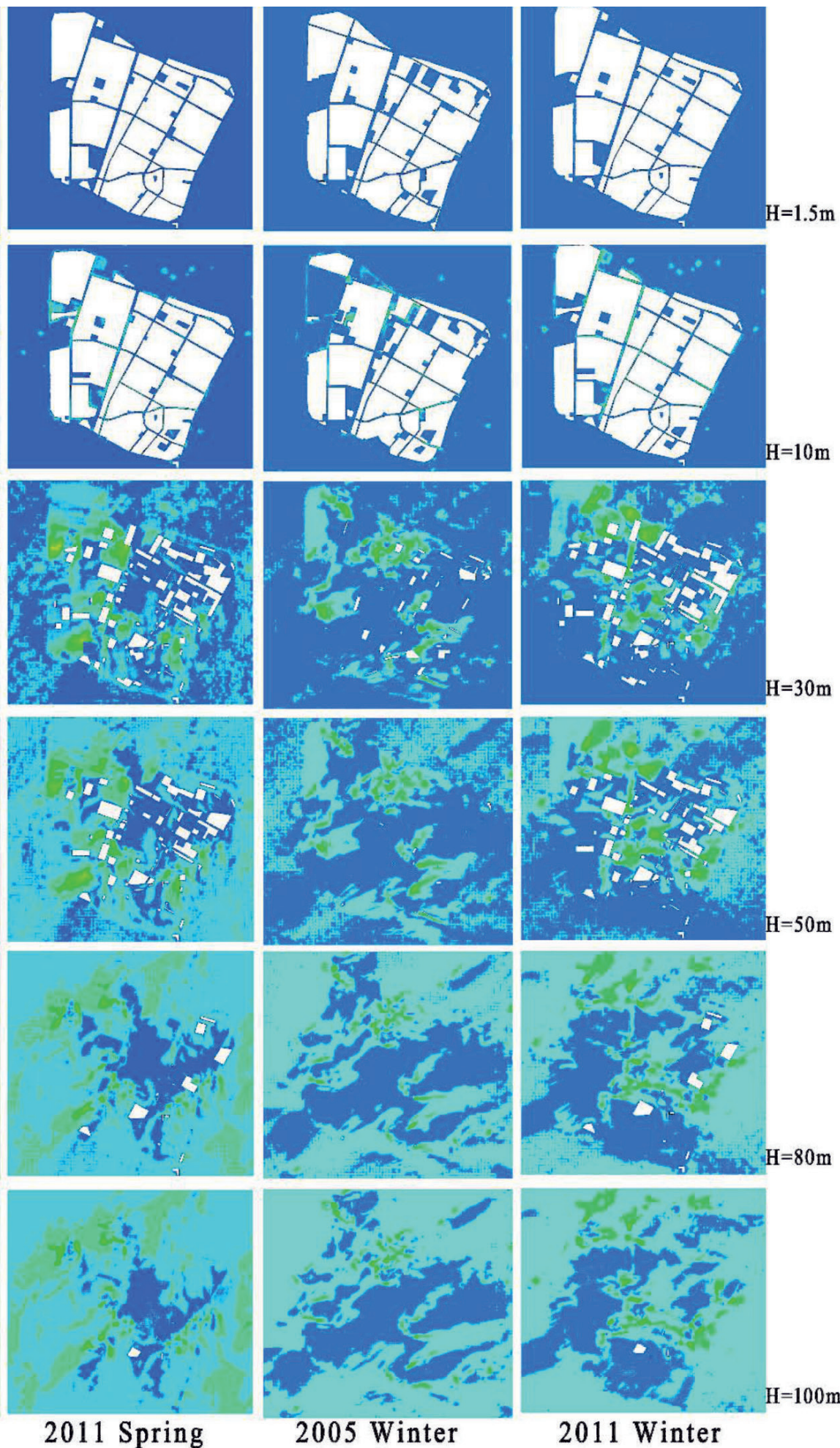

2005 Winter

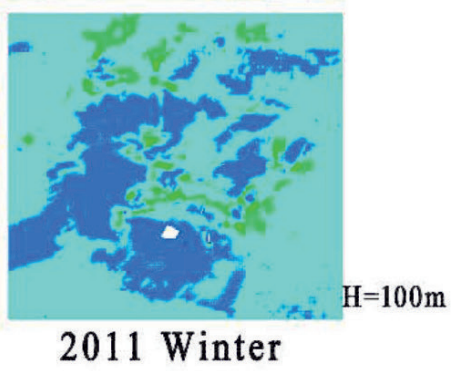

Fig. 3. Urban wind speed horizontal distribution at different vertical heights during winter and spring of 2005 and 2011. 


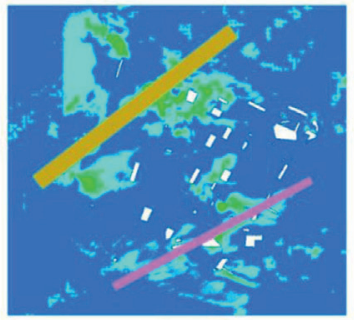

2005 Spring

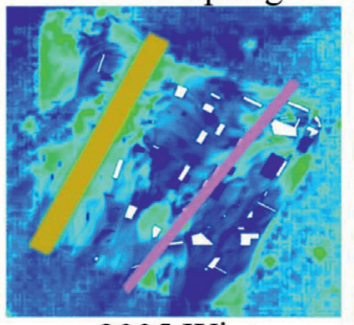

2005 Winter
Main wind corridor

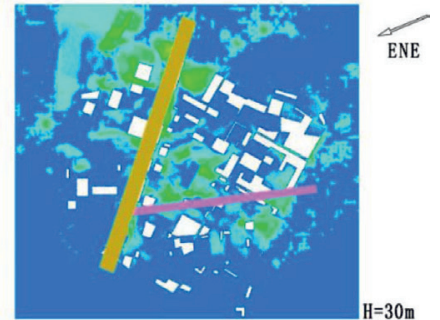

2011 Spring

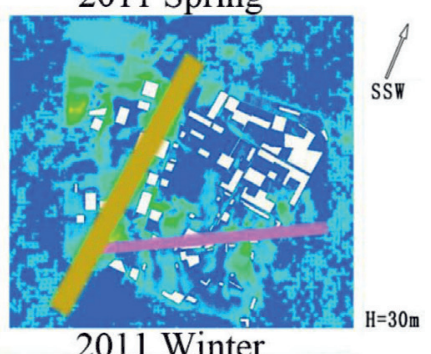

2011 Winter
Fig. 4. Urban ventilation corridor at a height of $30 \mathrm{~m}$ during the spring and winter of 2005 and 2011.

middle effect field, the wind speed on the windward side is greater than that on the leeward side. In the wind speed field of the top effect field, the speed field distribution of the wind tends to be stable.

Comparison of urban wind speed distributions at the same vertical height during the same season of 2005 and 2011 shows that with the vertical expansion of the city, building height and building density increased. Because of the drag effect of the building on the wind flow field, the area of the city affected by a stronger wind also increases. During the winter, the region with a high large wind speed is mainly the northwest and southeast parts of the city during 2005 and mainly the northwest, central and eastern parts of the city during 2011. During the spring, the region with a high wind speed is mainly the northeast and western half of the city during 2005 , but mainly the western and southern halves of the city during 2011. From the simulation results for the same season during 2005 and 2011, it can be seen that at the same height, the distribution area of the higher wind speed is greater than that of the former. It can be deduced that because the height of urban buildings and their density increases, the impact area of the higher wind speed increases as the distance from the ground increases.

By analyzing the distribution of the wind field in the Tiexi District, we obtained the distribution maps of ventilation corridors at a height of $30 \mathrm{~m}$ during the spring and winter of 2005 and 2011 (Fig. 4). From the urban ventilation corridor map we can see that there are two ventilation corridors, respectively, during the winter and spring of 2005 and 2011. During winter, the two corridors are nearly parallel, $48^{\circ}$ and $51^{\circ}$ north by east respectively during 2005. However, during 2011, two wind corridors converge in the southern part of the district. The main wind corridor is $18^{\circ}$ north of east, and the secondary wind corridor is $84^{\circ}$ north of east. During the spring, the two corridors are nearly parallel, $30^{\circ}$ and $43^{\circ}$ north of east respectively during 2005; however, the two corridors converge in the southern part of the city in 2011. The main wind corridor is $30^{\circ}$ north of east and the secondary wind corridor is $82^{\circ}$ north of east.

From 2005 to 2011, the main ventilation corridor in this area basically remains unchanged, while the secondary ventilation corridor obviously changed, with the change in the urban architectural landscape pattern occurring during the same season. In contrast to the urban ventilation corridors during the winter and spring of the same year, the ventilation corridors of the cities changed during 2005, but during 2011 they were nearly the same. The results show that with the change in the urban architecture landscape pattern, the corridor of the city significantly changed.

\section{Temperature Distribution of Different Heights}

The horizontal distribution of urban temperature at different vertical heights during the winter and spring of 2005 and 2011 is shown in Fig. 5. The common characteristic of horizontal diffusion of temperature at different vertical heights during the same year is that with the increase in height, the diffusion resistance of buildings to temperature distribution gradually decreases during the same season. The regional range of urban higher temperature increases first and then decreases with the increase in height. Thirty meters above the ground is the inflection point of the higher temperature, which is mainly distributed in the northern and central parts of the region. The temperature difference at the bottom of the region is the largest, followed by the middle field and the minimum at the top. During 2005, the higher temperature control areas were mainly in the north during the winter and northwest during the spring. In addition, during 2011, the higher temperature control areas were mainly in the south, central and eastern parts of the region during winter and south during spring. By comparing the horizontal diffusion of surface temperature at the same vertical height during 2005 and 2011, with the vertical expansion of the city, the building height and density increase, and the higher temperature area in the city increases.

\section{$\mathrm{SO}_{2}$ Distribution at Different Heights}

The horizontal distribution of $\mathrm{SO}_{2}$ concentration at different vertical heights during the winter and spring of 2005 and 2011 is shown in Fig. 6. The $\mathrm{SO}_{2}$ concentration distribution map indicates that the $\mathrm{SO}_{2}$ concentration in the windward area of the region is higher than that of the leeward side. With the increase in heights, the range of the influence of a higher concentration of $\mathrm{SO}_{2}$ increased first and then decreased. The largest distribution area of high concentration appears $30 \mathrm{~m}$ 


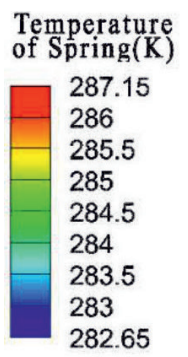

$\begin{gathered}\text { Temperature } \\
\text { of Winter (K) }\end{gathered}$
\begin{tabular}{|l}
275.15 \\
274.15 \\
272.15 \\
270.15 \\
268.15 \\
266.15 \\
264.15
\end{tabular}

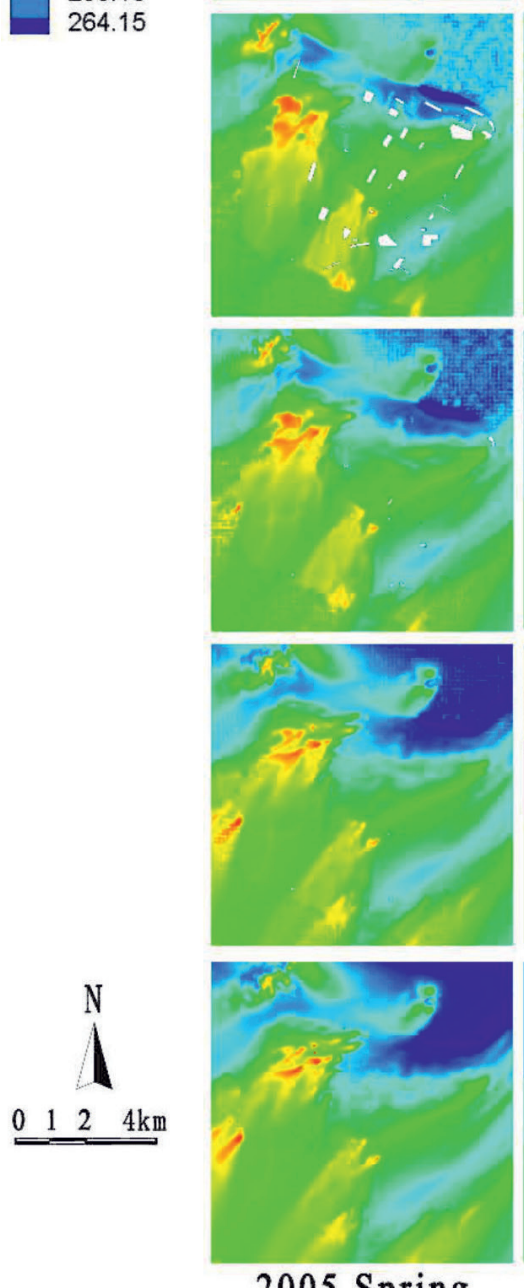

2005 Spring
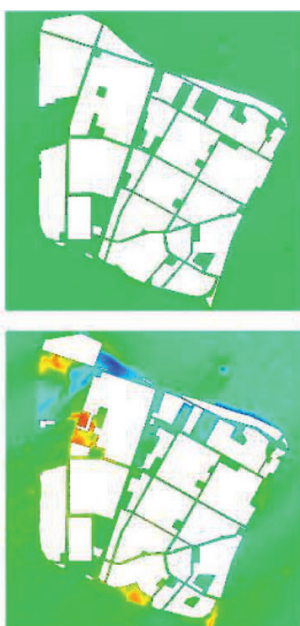
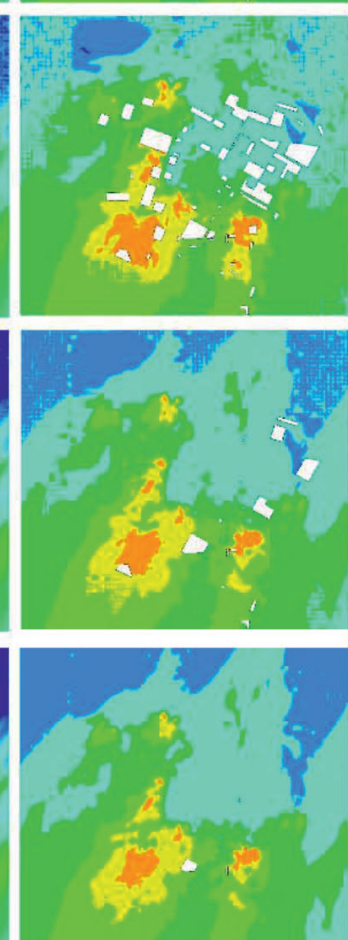

2011 Spring

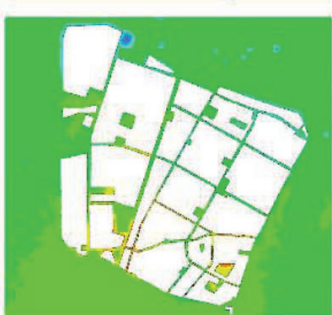

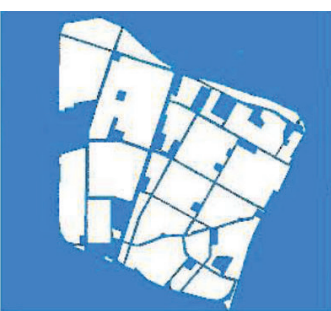
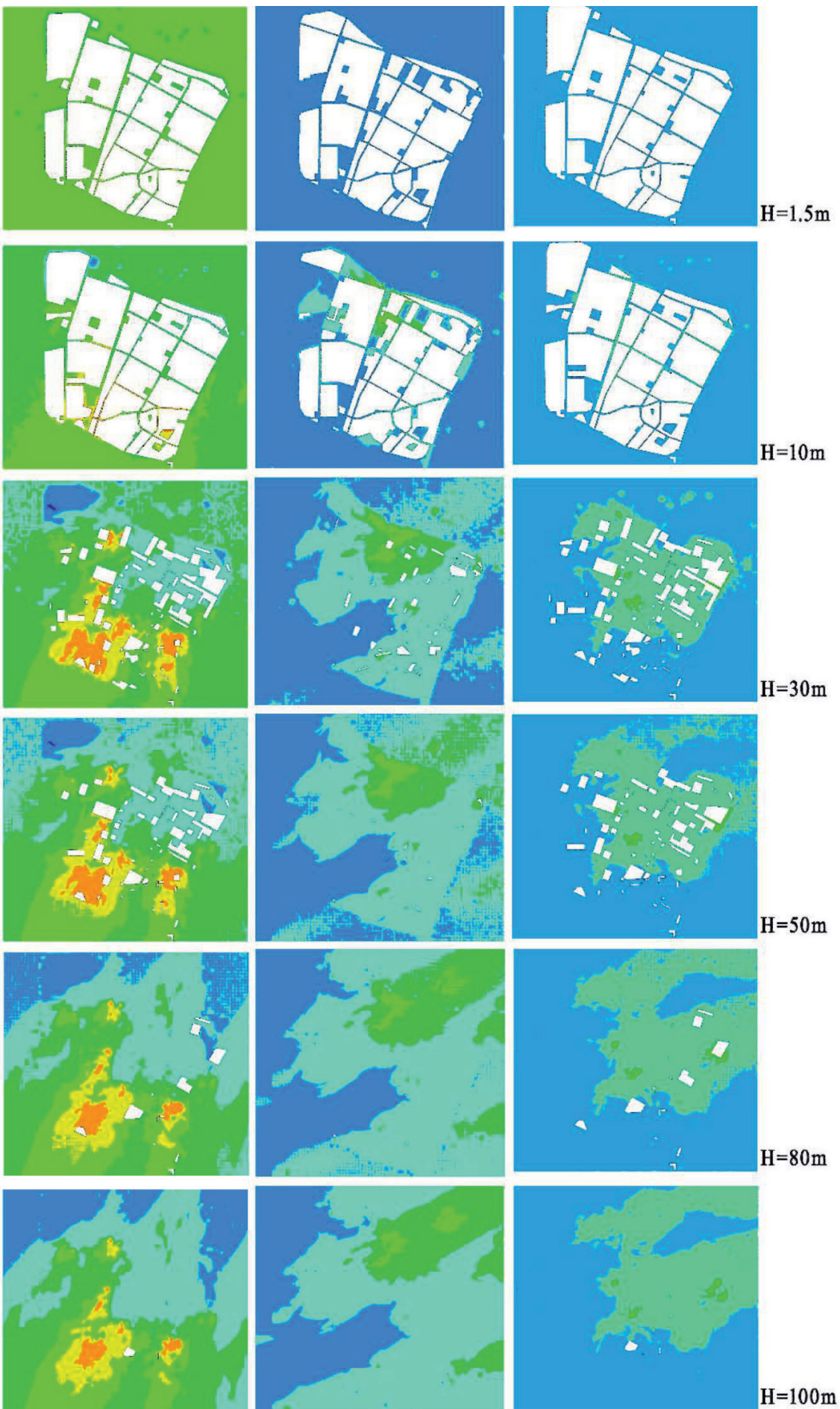

2005 Winter
2011 Winter

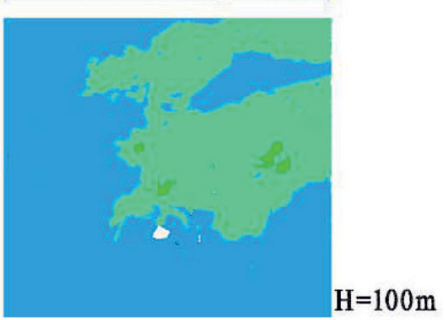

Fig. 5. Temperature horizontal distribution at different vertical heights during the winter and spring of 2005 and 2011.

above the ground. In the simulation range of the study area, the concentration difference at the bottom is the largest, followed by the middle, and the concentration difference at the top is the smallest. With the increase in height, the $\mathrm{SO}_{2}$ concentration in the urban area had not significantly changed.

Compared to the $\mathrm{SO}_{2}$ concentrations during 2005 and 2011, the vertical expansion of the city and the subsequent building height and density increase, the distribution area of $\mathrm{SO}_{2}$ higher concentration first increased and then decreased. During the winter, the concentrated distribution area of a high $\mathrm{SO}_{2}$ concentration in the region changes from one point to multiple points. During the winter of 2005, the high $\mathrm{SO}_{2}$ concentration area was largely on the north side of Baogong Street in the northern study area. During the winter of 2011, it was concentrated in the northeastern corner of the study area, on both sides 
of Baogong Street and the central and eastern parts of the study area. During the spring, the distribution of the high $\mathrm{SO}_{2}$ concentration area in the city changed from block dispersion to a planar concentration. During the spring of 2005, it was concentrated west of Baogong Street, while during spring 2011 it was concentrated west of Baogong Street and south of Jianshe Road.
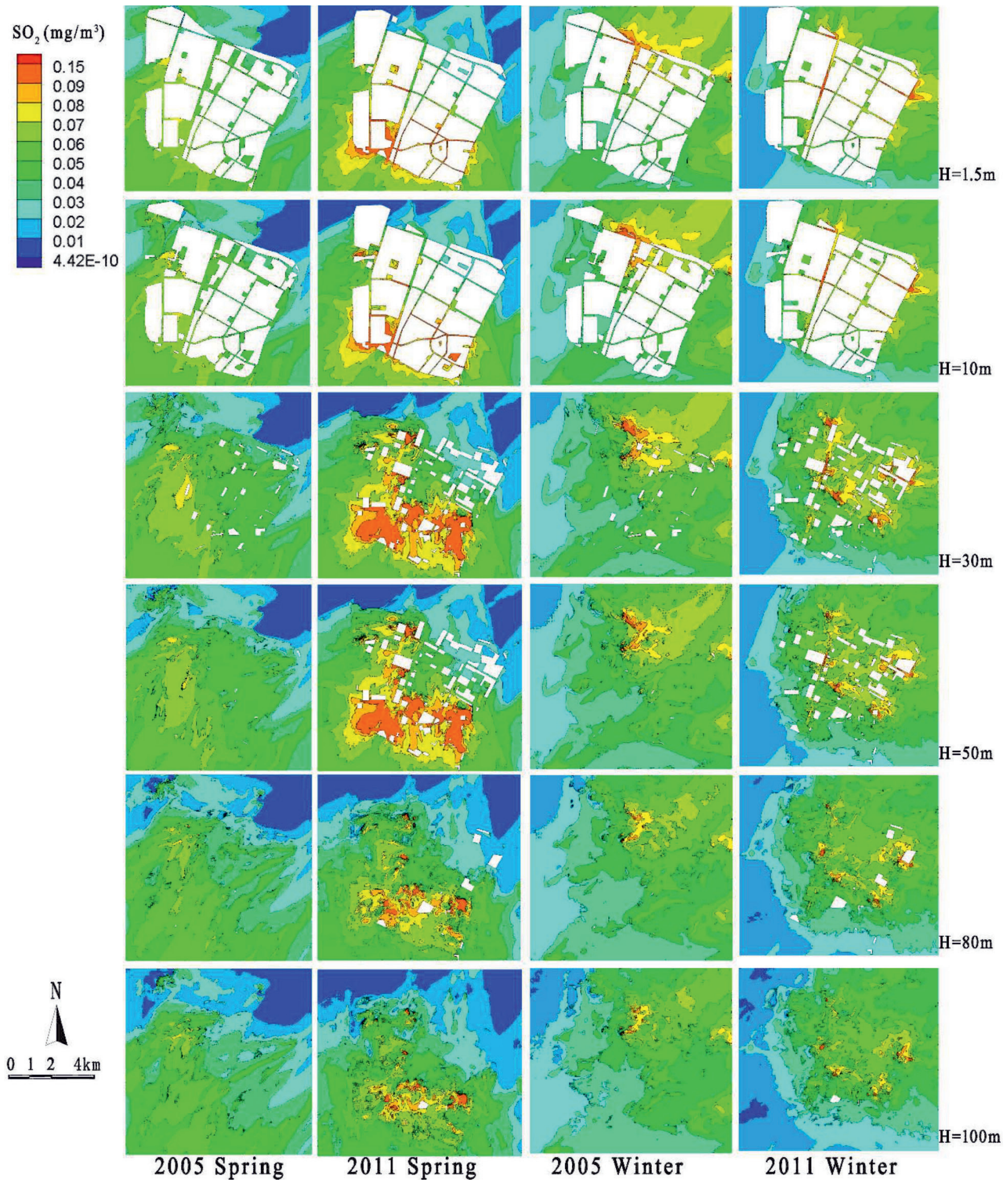

Fig. 6. $\mathrm{SO}_{2}$ horizontal distribution at different vertical heights during the winter and spring of 2005 and 2011. 
during winter, the distribution area of the high $\mathrm{SO}_{2}$ concentration during the spring is significantly larger than it is during the winter, which indicates that the $\mathrm{SO}_{2}$ has a greater impact on the study area when south is the dominant wind direction during the spring.

\section{Conclusions}

In this study, a CFD model was used to simulate the distribution of wind speed, temperature and $\mathrm{SO}_{2}$ concentration during winter and spring in the Shenyang Tiexi District under an urban landscape pattern of 2005 and 2011. The following conclusions were obtained:

(1) The wind speed along the windward side of the city is higher than that of the leeward side. The area affected by the high wind speed increases with an increase in height. In the wind speed field of the top effect field, the speed field distribution of the wind tends to be stable.

(2) The temperature difference at the bottom of the region is the largest, followed by the middle field and the minimum at the top. By comparing the horizontal diffusion of the surface temperature at the same vertical height during 2005 and 2011 with vertical expansion of the city, and subsequent building height and density increase, the higher temperature area in the city is increased.

(3) The $\mathrm{SO}_{2}$ concentration along the windward side of the city is higher than that of the leeward side. With the increase in height, the influence range of higher $\mathrm{SO}_{2}$ concentration values first increases and then decreases; $30 \mathrm{~m}$ in height above the ground is the inflection point. With the increase in height, the location of the higher $\mathrm{SO}_{2}$ concentration in the city did not significantly change.

(4) Under the same external conditions, with the increase in the vertical expansion of the city, and the subsequent building height and building density increase, the area affected by the higher wind speed and the higher polluted gas concentration increased at the same time at the same height of the city.

The influence of urban three-dimensional expansion on the atmospheric environment was simulated and analyzed, providing an important reference for urban planning and design, transformation policy and urban air quality control measures. However, the mechanism of urban expansion on the atmospheric environment needs further study, including quantitative study on the influence of urban land use, building landscape pattern and morphology on pollutant diffusion.

\section{Acknowledgements}

Funding for this project was provided by the Key Project of the National Natural Science Foundation of China (No. 41730647), the China National R\&D Program (No. 2017YFC0505704) and the National
Natural Science Foundation of China (Nos. 41871192, 41671185 and 41671184).

\section{Conflict of Interest}

The authors declare no conflict of interest.

\section{References}

1. PATHIRANA A., DENEKEW H.B., VEERBEEK W., ZEVENBERGEN C., and BANDA A.T. Impact of urban growth-driven landuse change on microclimate and extreme precipitation - A sensitivity study, Atmospheric Research 138, 59, 2014.

2. POURAHMAD A., BAGH V.A., ZANGENEHE S.S., and GIVEHCHI S. The impact of urban sprawl up on air pollution, 2007.

3. HARLAN S.L., RUDDELL D.M. Climate change and health in cities: impacts of heat and air pollution and potential co-benefits from mitigation and adaptation, Curr. Opin. Environ. Sustain. 3 (3), 126, 2011.

4. ZHAO Y., HU J., TAN Z., LIU T., ZENG W., LI X., HUANG C., WANG S., HUANG Z., and MA W. Ambient carbon monoxide and increased risk of daily hospital outpatient visits for respiratory diseases in Dongguan, China, Science of the Total Environment 668, 254, 2019.

5. WANG C., FENG L., CHEN K. The impact of ambient particulate matter on hospital outpatient visits for respiratory and circulatory system disease in an urban Chinese population, Science of the Total Environment 666, 672, 2019.

6. SHOU Y., HUANG Y., ZHU X., LIU C., HU Y., and WANG H. A review of the possible associations between ambient PM2.5 exposures and the development of Alzheimer's disease, Ecotoxicology and Environmental Safety 174, 344, 2019.

7. CHEN Y., ZHENG M., LV J., SHI T., LIU P., WU Y., FENG W., HE W., and GUO P. Interactions between ambient air pollutants and temperature on emergency department visits: Analysis of varying-coefficient model in Guangzhou, China, Science of the Total Environment 668, $825,2019$.

8. ZHAO M., CAI H., QIAO Z., XU X. Influence of urban expansion on the urban heat island effect in Shanghai, International Journal of Geographical Information Science 30 (12), 2421, 2016.

9. CHEN X.-L., ZHAO H.-M., LI P.-X., YIN Z.-Y. Remote sensing image-based analysis of the relationship between urban heat island and land use/cover changes, Remote Sensing of Environment 104 (2), 133, 2006.

10. WENG Q. A remote sensing-GIS evaluation of urban expansion and its impact on surface temperature in the Zhujiang Delta, China, International Journal of Remote Sensing 22 (10), 1999, 2001.

11. YOKOBORI T., OHTA S. Effect of land cover on air temperatures involved in the development of an intraurban heat island, Climate Research 39 (1), 61, 2009.

12. NONOMURA A., KITAHARA M., MASUDA T. Impact of land use and land cover changes on the ambient temperature in a middle scale city, Takamatsu, in Southwest Japan, Journal of Environmental Management 90 (11), 3297, 2009. 
13. RODRIGUEZ M.C., DUPONT-COURTADE L., OUESLATI W. Air pollution and urban structure linkages: Evidence from European cities, Renewable \& Sustainable Energy Reviews 53, 1, 2016.

14. STONE B., JR. "Urban sprawl and air quality in large US cities, Journal of Environmental Management 86 (4), 688, 2008.

15. HAN L., ZHOU W., LI W., MESHESHA D.T., LI L., ZHENG M. Meteorological and urban landscape factors on severe air pollution in Beijing, Journal of the Air \& Waste Management Association 65 (7), 782, 2015.

16. QIAO Z., WU F., XU X., YANG J., LIU L. Mechanism of Spatiotemporal Air Quality Response to Meteorological Parameters: A National-Scale Analysis in China, Sustainability 11 (14), 3957, 2019.

17. LI W., SUN S. Air pollution driving factors analysis: Evidence from economically developed area in China, Environmental Progress \& Sustainable Energy 35 (4), 1231, 2016.

18. FAN C., TIAN L., ZHOU L., HOU D., SONG Y., QIAO X., LI J. Examining the impacts of urban form on air pollutant emissions: Evidence from China, Journal of Environmental Management 212, 405, 2018.

19. MCCARTY J., KAZA N. Urban form and air quality in the United States," Landscape and Urban Planning 139, 168, 2015.

20. DE RIDDER K., LEFEBRE F., ADRIAENSEN S., ARNOLD U., BECKROEGE W., BRONNER C., DAMSGAARD O., DOSTAL I., DUFEK J., HIRSCH J., INT PANIS L., KOTEK Z., RAMADIER T., THIERRY A., VERMOOTE S., WANIA A., WEBER C. Simulating the impact of urban sprawl on air quality and population exposure in the German Ruhr area. Part II: Development and evaluation of an urban growth scenario, Atmospheric Environment 42 (30), 7070, 2008.

21. PARK C., HA J., LEE S. Association between ThreeDimensional Built Environment and Urban Air Temperature: Seasonal and Temporal Differences, Sustainability 9 (8), 2017.

22. FANG F., ZHANG T., PAVLIDIS D., PAIN C.C., BUCHAN A.G., NAVON I.M. Reduced order modelling of an unstructured mesh air pollution model and application in 2D/3D urban street canyons, Atmospheric Environment 96, 96, 2014.

23. CHEN L., NG E., AN X., REN C., LEE M., WANG U., HE Z. Sky view factor analysis of street canyons and its implications for daytime intra-urban air temperature differentials in high-rise, high-density urban areas of Hong Kong: a GIS-based simulation approach, International Journal of Climatology 32 (1), 121, 2012.

24. TOPARLAR Y., BLOCKEN B., MAIHEU B., VAN HEIJST G.J.F. A review on the CFD analysis of urban microclimate, Renewable and Sustainable Energy Reviews 80, 1613, 2017.

25. BLOCKEN B. Computational Fluid Dynamics for urban physics: Importance, scales, possibilities, limitations and ten tips and tricks towards accurate and reliable simulations, Building and Environment 91, 219, 2015.

26. KANDA M. Progress in Urban Meteorology: A Review, Journal of the Meteorological Society of Japan. Ser. II 85 (3), 363, 2007.

27. MOONEN P., DEFRAEYE T., DORER V., BLOCKEN B., CARMELIET J. Urban Physics: Effect of the microclimate on comfort, health and energy demand, Frontiers of Architectural Research 1 (3), 197, 2012.
28. RIZWAN A.M., DENNIS L.Y.C., LIU C. A review on the generation, determination and mitigation of Urban Heat Island," Journal of Environmental Sciences 20 (1), 120, 2008.

29. TOMINAGA Y., STATHOPOULOS T. CFD simulation of near-field pollutant dispersion in the urban environment: A review of current modeling techniques, Atmospheric Environment 79, 716, 2013.

30. LIU S., PAN W., ZHANG H., CHENG X., LONG Z., CHEN Q. CFD simulations of wind distribution in an urban community with a full-scale geometrical model, Building and Environment 117, 11, 2017.

31. RAMPONI R., BLOCKEN B., DE COO L.B., JANSSEN W.D. CFD simulation of outdoor ventilation of generic urban configurations with different urban densities and equal and unequal street widths," Building and Environment 92, 152, 2015.

32. JIN M., ZUO W., CHEN Q. Simulating Natural Ventilation in and Around Buildings by Fast Fluid Dynamics, Numerical Heat Transfer, Part A: Applications 64 (4), 273, 2013.

33. BROWN K., KALATA W., SCHICK R. Optimization of SO2 Scrubber Using CFD Modeling, Procedia Engineering 83, 170, 2014.

34. MIAO Y., GUO J., LIU S., ZHAO C., LI X., ZHANG G., WEI W., MA Y. Impacts of synoptic condition and planetary boundary layer structure on the trans-boundary aerosol transport from Beijing-Tianjin-Hebei region to northeast China, Atmospheric Environment 181, 1, 2018.

35. LI X., WANG Y., SHEN L., ZHANG H., ZHAO H., ZHANG Y., MA Y. Characteristics of Boundary Layer Structure during a Persistent Haze Event in the Central Liaoning City Cluster, Northeast China, Journal of Meteorological Research 32 (2), 302, 2018.

36. XU Y., LIU M., HU Y., LI C., XIONG Z. Analysis of Three-Dimensional Space Expansion Characteristics in Old Industrial Area Renewal Using GIS and Barista: A Case Study of Tiexi District, Shenyang, China, Sustainability 11 (7), 1860, 2019.

37. China International Exchange Station Ground Climate Standard Value Daily Data Set, National meteorological information center, http:/data.cma.cn/data/detail/ dataCode/SURF_CLI_CHN_MUL_DAY_CES_V3.0.html (2019).

38. ZHANG P., HU Y., XIONG Z. Extraction of ThreeDimensional Architectural Data from QuickBird Images, Journal of the Indian Society of Remote Sensing 42 (2), 409, 2014

39. Technical policy on prevention and control of sulfur dioxide emissions from coal burning, Ministry of Ecology and Environment of the People's Republic of China, http://kjs.mee.gov.cn/hjbhbz/bzwb/wrfzjszc/200607/ t20060725_91282.shtml (2002).

40. RICHARDS P.J., NORRIS S.E. Appropriate boundary conditions for computational wind engineering models revisited, Journal of Wind Engineering and Industrial Aerodynamics 99 (4), 257, 2011.

41. LAUNDER B.E., SPALDING D.B. The numerical computation of turbulent flows, Computer Methods in Applied Mechanics and Engineering 3 (2), 269, 1974.

42. LI N., WANG Z., ZHANG Z. Influence of plant structure and flow path interactions on the plant purification system: dynamic evolution of the $\mathrm{SO}_{2}$ pollution, Environmental Science and Pollution Research 25 (35), 35099, 2018.

43. FRANKE J., HELLSTEN A., SCHLUENZEN K.H., CARISSIMO B. The COST 732 Best Practice Guideline 
for CFD simulation of flows in the urban environment: a summary, International Journal of Environment and Pollution 44 (1-4), 419, 2011.

44. TOMINAGA Y., MOCHIDA A., YOSHIE R., KATAOKA H., NOZU T., YOSHIKAWA M., SHIRASAWA T., AIJ guidelines for practical applications of CFD to pedestrian wind environment around buildings, Journal of Wind Engineering and Industrial Aerodynamics 96 (10-11), 1749, 2008.

45. SOLAZZO E., VARDOULAKIS S., CAI X. A novel methodology for interpreting air quality measurements from urban streets using CFD modelling, Atmospheric Environment 45 (29), 5230, 2011.

46. PONTIGGIA M., DERUDI M., ALBA M., SCAIONI M., ROTA R. Hazardous gas releases in urban areas: Assessment of consequences through CFD modelling, Journal of Hazardous Materials 176 (1-3), 589, 2010.

47. ASHIE Y., KONO T. Urban-scale CFD analysis in support of a climate-sensitive design for the Tokyo Bay area, International Journal of Climatology 31 (2), 174, 2011. 
